\title{
RIGOROUS FUNDAMENTALS OF CLASSIFICATION OF LIGHT-INDUCED BEHAVIOUR FROM FREELY MOTILE MICROORGANISMS
}

\author{
Nadia P. MASSJUK \& Yuriy I. POSUDIN
}

\begin{abstract}
SUMMARY. Rigorous fundamentals of classification of light-induced behaviour from freely motile microorganisms. The revision of terminology and classification principles of the types of light-dependent movement behaviour of freely motile organisms and their populations has demonstrated the presence of various classification systems being the source of the terminological confusion. It is shown that the present classification and definition of the terms had a number of logical mistakes. The primary meaning of the term "phototopotaxis" which implies any lightdependent movement behaviour of freely motile organisms is proposed. It is possible to use the restored term "phototopotaxis" for definition of the movement oriented relative to the light stimulus. The parametrical principle of the classification of the types of phototaxis for a single or a population of cells is recommended for the first time. According to this principle it is possible to put in order the available facts and terminology on the strict logical basis, to forecast the dependence of the movement parameters of the biological objects on the light stimulus characteristics which has been not established till now, and to develop the program of further research. The parametrical principle could also be used for the classification of taxa induced by any stimuli. The photoreaction (immediate response to any change of the light stimulus) of freely motile organisms is discussed as a part of the more general meaning - phototaxis.
\end{abstract}

Key words. Algae, classification, photomovement, terminology.

RESUMEN. Fundamentos rigurosos de la clasificación del comportamiento inducido por la luz de microorganismos móviles. La revisión de la terminología y principios de la clasificación de los tipos de movimientos dependientes de la luz en organismos móviles, así como en sus poblaciones, ha mostrado la existencia de diferentes sistemas de clasificación incongruentes entre sí, y que dan lugar a una gran confusión de términos. En particular, el sistema actual de clasificación y definición de términos adolece de ciertos errores relacionados con la lógica formal. Se propone el uso del término "fototopotaxis" en su definición inicial, cualquier movimiento de un organismo móvil que es dependiente de la luz. Así, se puede usar este término para definir el movimiento en relación a la orientación relativa de la fuente de luz. Se sugiere, por primera vez, el uso del principio paramétrico de la clasificación de los tipos de fototaxis, bien para una sola célula o para una población de células. De acuerdo con este principio, es posible poner orden en la terminología relacionada con los tipos de movimiento siguiendo estrictamente los criterios de la lógica formal, predecir la dependencia de los parámetros de movimiento del obejto biológico en relación a las características del estímulo lumínico (lo cual no se había tenido en cuenta hasta ahora), y desarrollar futuros programas de investigación. El principio paramétrico de clasificación también podría usarse para la clasificación de los taxa, en relación con cualquier tipo de estímulo. Se discute el significado del término fotoreacción (respuesta inmediata a cualquier tipo de cambio en el estímulo lumínico), aplicable a organismos móviles, en el contexto más amplio de la fototaxis.

Palabras clave. Algas, clasificación, fotomovimiento, terminología. 


\section{INTRODUCTION}

Nowadays the problem of photomovement and photoregulation of microorganisms is being investigated rather extensively. This may be explained by the importance of these phenomena, which are connected with fundamental processes of viability such as photosynthesis, energy transduction, membrane-coupled and membrane-mediated phenomena. The investigations of photomovement and its photoregulation are directly related to the elucidation of general principles of intracellular processes of metabolism, as wells ontogenesis. These investigations may play a fundamental role for ecology and biocenology, because light is an important factor for spatial and temporal distribution of microorganisms, which has an independent function and at the same time informs us about the complexity of related environmental factors related to it (i.e., temperature, $\mathrm{pH}$, biogenous compounds and oxygen content, the presence of other microorganisms, etc.) (Kritsky, 1982; Sineschekov \& Litvin, 1982). The investigation of photomovement mechanisms is also of interest from the standpoint of bionics, evolutionary biology and morphology, phylogeny and systematic. It is known, for example, that the structure of the motor apparatus and photoreceptor is an important systematic character at the higher taxonomic levels (divisions and classes) in phycology (Sedova, 1977; Topachevsky \& Massjuk, 1984; van den Hoek et al., 1995; Graham \& Wilcox, 2000). Thus, it is possible to assume the specificity of the mechanisms of photoperception and photoregulation of photomovement between the members of different divisions or classes of algae. Finally, the investigation on photomovement regularity could be of practical use in research fields such as biomonitoring of environment, biotechnology, natural products from valuable organisms, etc.

Intense investigations in any field usually result in enrichment, revision and alteration of old terminology because new information requires new terms to be properly understood. At the present, this process is occuring in the field of photomovement of microorganisms as well. The problems concerning terminology and classification of the phenomena associated with the motile properties of microorganisms were paid much attention by numerous researchers (Halldal, 1958; Jahn \& Bovee, 1968; Nultsch, 1975, 1980; Diehn et al., 1977; Feinleib, 1977, 1978, 1980; Lenci \& Colombetti, 1978; Diehn, 1979; Nultsch \& Häder, 1979; Häder, 1979; Lenci, 1982; Colombetti \& Lenci, 1982; Colombetti et al., 1982; Sineschekov \& Litvin, 1982; Posudin, 1982, 1985; Haupt, 1983; Lenci et al., 1984; Burr, 1984; Lee, 1989; Massjuk \& Posudin, 1991; Massjuk et al., 1991; Posudin et al., 1988, 1990, 1991a, 1992a, 1992b, 1993, 1995, 1996; Witman, 1993; Kreimer, 1994; Häder, 1996; Martynenko et al., 1996; Posudin \& Massjuk, 1996; Sineschekov \& Govorunova, 1999; Lebert \& Häder, 2000; Photomevement, 2001). However, definition of terms and concepts still remains rather ambiguous. Sometimes the new meaning is attached to old terms (e.g., "phototaxis"), the same term (e.g., "photokinesis") is interpreted differently by various authors (e.g., compare Diehn et al., 1977; Nultsch \& Häder, 1979), or, on the contrary, different terms are used as synonyms (e.g., "photomovement", "photobehaviour", "photomotion", "photoreaction", "photoresponse", "photoregulation of movement", "light response", "light-induced behavioural response", "motile behaviour", "behavioural light response", "photobehaviour response", "behavioural response", "light controlled movement", "light controlled cell motility", "movement behaviour", "photoinduced behaviour", "photomovement response", "photomotile response", "motile response to light") (Posudin, 
1982, 1985; Sineschekov \& Litvin, 1982; Sineschekov \& Govorunova, 1999; Govorunova et al., 2000, 2001; Photomovement, 2001). At the present there are several proposals of terminology which describe the motile behaviour of organisms (e.g., Fraenkel \& Gunn, 1961; Burr, 1984); this fact hinders reaching the mutual understanding between scientists in this field.

The present article is aimed to the discussion of the logical bases of classification of phenomena, which are related to the photomovement of freely motile organisms, and to the definition of corresponding terminology.

\section{STATE OF THE ART}

The photomotile reactions of organisms were noted for the first time early in the nineteenth century (Treviranus, 1817, cyt. by Nultsch, 1975). Strasburger (1878, cyt. by Nulsch, 1975) was the first author to suggest the distinction between photoreaction of motile (phototaxis) and fixed (phototropism) organisms; so, according to this author the phototaxis denotes the photic reaction of freely moving organisms. Just in this sense, this term took a definite place in a larger system which denote the displacement in space of freely motile organisms due to different environmental factors: chemical (chemotaxis), thermal (thermotaxis), gravitational (gravitaxis), mechanical (mechanotaxis), etc. This term, in a regular way, just in this meaning took its place between various terms which denote the photobiological reaction in the system of terms describing the general functional-physiological reactions (Konev \& Volovsky, 1979).

However, early in the nineteenth century the term "phototaxis" was used in a more close meaning to denote the oriented motion relative to the light source (Nagel, 1901, cyt. by
Fraenkel \& Gunn, 1961; Nultsch, 1975). Just this time Pfeffer (1904, cyt. by Fraenkel \& Gunn, 1961; Nultsch, 1975) suggested the special term "phototopotaxis" for the photoorientated movement of organisms which have been accepted by investigators and have been widely used during the following decades (see e.g., Halldal, 1958). But Diehn (1970) suggested the term "phototaxis" for the oriented movement of organisms in response to a light stimulus, so giving up the term "phototopotaxis".

In his earlier works, Nultsch (1975) has also indicated that "greek word "taxis" in its original sense denotes only a distinct spatial array, and so the term "phototaxis" should mean any array of organisms in space caused by light and is not restricted to their direct movement". Moreover, the special term "phototopotaxis" exists for denoting all above mentioned phenomena. However, this author demonstrated some kind of inconsequence in his following works while accepting the narrow interpretation of the term "phototaxis", which was criticized by him earlier (Nultsch \& Häder, 1979; Nultsch, 1980). Following Diehn's proposal (Diehn, 1970), the narrow interpretation of the term "phototaxis" as a movement oriented relative to the stimulus direction was accepted by many authors (Fraenkel \& Gunn, 1961; Diehn et al., 1977; Feinleib, 1977, 1978, 1980; Lenci \& Colombetti, 1978; Mikolajczyk \& Diehn, 1978, 1979; Häder, 1979; Sineschekov \& Litvin, 1982; Posudin, 1982, 1985; Burr, 1984; Kawai \& Kreimer, 2001; Flores-Moya et al., 2002).

It should be noted that the narrow interpretation of the term, which has the more diverse meaning is the violation of the requirements of the formal logic, which leads to disagreement in terminology. New interpretation of the term "phototaxis" resulted in the appearance of many different equivalents for filling a gap in terminology. Instead or a abort and distinct term "phototaxis" one can meet expressions such as "photomovement", 
"photomotion", "photobehaviour", "motile behaviour", "motility behaviour patterns", "phototactic reactivity", "phototopotaxis", "light induced response of freely moving microorganisms", "response type", "photoresponses", "response strategies", "behavioural responses", "phototactic orientation", "phototactic response", "orientation reactions", "photoorientation", "phototactic movement" etc. (Feinleib, 1977, 1980; Lenci \& Colombetti, 1978; Nultsch \& Häder, 1979; Kuznitski \& Mikolajczyk, 1982; Sineschekov \& Litvin, 1982; Posudin, 1982, 1985; Morel-Laurens \& Feinleib, 1983; Pfau et al., 1983, Nultsch, 1983, Häder \& Lebert, 1998; Horiguchi et al., 1999; Yoshihara et al., 2000; Lebert \& Häder, 2000). The same situation can be mentioned with the term "photophobic response" - it is possible to meet synonyms such as "photoshock", "photoshock response", "photoshock cell response", "photophobic, stop or ecclitic response", "photophobotaxis", "stop response", "light induced stop response" (Beckmann \& Hegemann, 1991; Hegemann et al., 1991; Govorunova et al., 1997; Holland et al., 1997; Matsuda et al., 1998; Sineschekov \& Govorunova, 1999; Lebert \& Häder, 2000; Photomovement, 2001). The plurality and diversity of these expressions are undesirable. New designations are either bulky or not exact and concrete and they may be interpreted both in a wider meaning (e.g., including phototropism, photoregulation, etc.) and in a more narrow one. Some authors use these expressions as synonyms, while others distinguish photocontrol and its consequences (photomovement, photomotion) as well as photoresponses and behavioural consequences. It makes the undesirable disagreement in terminology more considerable.

Taking into account the above-mentioned considerations, we suggest to keep to the primary interpretation of term "phototaxis" as some kind of the light-induced displacement in space of freely motile organisms. Thus, in the photooriented movement of organisms it is possible to use the term "phototopotaxis" extended with two basical patterns: positive (towards the light source) and negative (away from it) (Halldal, 1958; Nultsch, 1975; Feinleib, 1980). Sometimes, a third pattern could be considered, the transverse phototopotaxis (perpendicular orientation relative to the light course) (Diehn et al., 1977; Diehn, 1979; Häder, 1979). According to the last point of view it is possible to consider any translation movement as oriented in relation to the light direction with the exception of diffused light or simultaneous illumination from all sides.

The term "photomovement" should have a more wide meaning: any motility response or its alteration induced by light. Thus, this term involves either phototaxis (in a wider meaning) or phototropism (e.g., compare with Nultsch \& Häder, 1979). In that way the terms "photomovement" and "phototaxis" are compatible, but not identical: the former has the subordinating character, while the latter had the subordinate one.

It is quite clear that the control of movement and photomovement of organisms are absolutely different processes being in the discrepancy in the causal-effect relationship: photomovement of organisms is a consequence of the control of movement.

As far ago as in the late nineteenth century, Engelmann (1882) observed a sharp change in the direction of the movement of some microorganisms due to sudden increasement of the light intensity; this response of microorganisms was called "phobic" ("Schreckbewengung"). This author also noticed the restoration of movement of the microorganisms, which remained immobile in the dark after switching on the light stimulus and he named this phenomenon as "photokinesis". These terms were kept up-todate although their interpretation suffered essential alterations. Thus, there are at least four different interpretation for the term 
"photokinesis" which evidence for an essential discrepancy in the interpretation of "phototaxis" and "photophobic response" (Burr, 1984). The following years give rich harvest of new terms (see e.g., Fraenkel \& Gunn, 1961) whose appearance and interpretation were discussed in details in a review from Nultsch (1975). As the author noted the disagreement in terminology "led to errors and misinterpretation, so that the creation of new terms would further confuse the situation rather than clarify it". This fact caused the creation of the Committee on Behaviour Terminology that was convened at the Conference on Sensory Transduction in Microorganisms in Santa Barbara, California, in January 1976. The recommendations of this Committee were published and signed by prominent photobiologists from various countries (Diehn, Feinleib, Haupt, Hildebrand, Lenci and Nultsch). As far as these recommendations are mentioned by the next investigators is the field of photobiology we shall discuss it in detail. There are three main sections in this nomenclature: 1. Stimuli; 2. Responses; and, 3. Behavioural consequences. The first section denotes a stimulus as any quantity of energy or matter which, when interacting with the organism, can elicit a response. The nature of the stimulus is indicated by prefixing the term for the response: photo(stimulus is a radiant energy affecting specific receptor molecules), thermo- (thermal energy), galvano- (ionic electric current), electro(electrical field), geo- or gravi- (gravitational force), mechano- (mechanical force), magneto(magnetic field), chemo-(molecular species acting upon specific receptor molecules). These recommendations are in agreement with the requirements of formal logic; nothing can be said against, so they are considered to be generally accepted (Burr, 1984). The authors pay attention to the nature of the stimulus because some physical factors (e.g., radiation or electrical energy) are capable of generation of chemical substances that may serve as direct stimuli. They also suggest to distinguish the dependence of response upon an increase ("step-up") and decrease ("step-down") of the stimulus intensity. The next section is devoted to the definition of response as any stimulusinduced alteration in the activity of the organisms motor apparatus which may (but not always) result in an alteration of the movement or orientation of the organisms. But further, during the classification of the types of responses, the authors discuss the levels of the organism: activity but not the activity of the motor apparatus from the organisms (Diehn et al., 1977). Thus, the definition which was proposed by the Committee for the term "response" does not correspond exactly to its meaning.

The Committee proposed to distinguish two main types of the responses: steady-state (kinesis) and transient (phobic responses) (Diehn et al., 1977). Both types of responses are responsible for both the change in the linear velocity and the change in the direction of movement. The former is controlled by the absolute magnitude of the stimulus intensity, while the latter is controlled by a temporal stimulus gradient. Obviously, the interpretation of these terms changed as compared to the primary variant (Engelmann, 1882). Besides, according to Diehn et al. (1977), phobic responses that have long adaptation time are nearly indistinguishable from kinesis. In such cases the choice of one or another term depends on the investigator. In such a way the classification of the responses which was suggested by the Committee (kinesis and phobic responses) suffers the absence of common efficient basis of division from the standpoint of formal logic. The classification of responses according to the presence or absence of adaptation does not suit the zoologists as well (Burr, 1984). It is beyond understanding the fact that the authors take into account only one of the light stimulus parameter - its intensity 
(absolute magnitude or temporal gradient), but they ignore parameters such as spectral composition, polarization, etc. The fact is that the same authors use notions such as "action spectrum of photokinesis" in their other publications (Nultsch, 1975; Nultsch \& Häder, 1979; Colombetti et al., 1982), which testify to the dependence of the movement of the organisms upon the wavelength of light stimulus.

Unfortunately, there is no definition of the term "behavioural consequences" in the third section. Therefore it is not clear which criterion is assumed as a basis of the division "responses" and "behavioural consequences", the authors consider two types of "consequences". The former concerns single cells and its movement oriented relative to the stimulus direction; the latter applies the population of organisms and shows the accumulation in a region with a higher intensity of a stimulus or dispersal from it of these organisms. In other words, the results of responses of organisms, which are affected by the stimulus, must be considered at the level of individuals (microeffect) or their aggregation (macroeffect). Thus, according to Diehn et al. (1977) and Diehn (1979) a taxis is the result of a response or of a series of responses of the motor apparatus rather than a single response. We have discussed earlier that it is unsuitable to use the wide meaning of the terms "taxis", in the narrow interpretation of photoorientation of organisms.

In spite of the fact that above-motioned publication (Diehn et al., 1977) was the result of the whole Committee activity only one of its memberships followed the recommendations in a sense of terminology. Nevertheless the other authors (Feinleib, 1978, 1980; Lenci \& Colombetti, 1978; Nultsch \& Häder, 1979; Nultsch, 1980; Lenci, 1982; Colombetti \& Lenci, 1982; Haupt, 1983; Lenci et al., 1984) accepted the classification that was previously suggested by Nultsch (1975). The majority of the photobiologists acts in such a way (see e.g., Sineschekov \& Litvin, 1982). This classification was presented in detail in the review from Nultsch \& Häder (1979). The authors did not accept the division on "responses" and "behavioural consequences" that was proposed by the Committee and they consider three types of responses of freely moving organisms:

1. Photokinesis: describes the effect of light intensity on the velocity of movement.

2. Phototaxis: is a movement oriented relative to light direction.

3. Photophobic response: is a reaction caused by the temporal change of light intensity, $d I / d t$, often a stop response followed by a reversal movement.

First of all, it should be noted that this classification has nothing in common with the recommendations of the Committee, although the authors were the members of it. Phototaxis (in narrow meaning) is considered not as a result of a response (or of a series of responses) of microorganisms at an individual level (Diehn et al., 1977), but as a response which has its own mechanism. Contrary to recommendations of the Committee, the interpretation of the term "photokinesis" and the sense meaning of the term "photophobic response" changed. Besides, the classification of these authors (Nultsch, 1975; Nultsch \& Häder, 1979) suffers with a number of logic mistakes. The requirements of the formal logic are not kept in the sense of definition of terms "photokinesis" and "phototaxis" and their correspondence to such meanings as generic and specific distinction. Thus, photokinesis is interpretated not as a type of a response, but as "the effect"; phototaxis - not as a type of a response - but as a "movement". Such definitions lead these terms out the meaning "photoresponse" due to their interpretation through the genus of other meanings ("effect", "movement").

It is not difficult to notice that the following features characterize this classification: 1. The common basis of division is absent; 2 . 
The members of the division do not exclude each other (e.g., the definition of photophobic reaction coincides with the definition of phototaxis); and 3. It is a leap in the division (e.g., phototaxis and photophobic reaction are terms of different levels).

It must be pointed out that classifications elaborated by microbiologists were criticized severely by zoologists. In particular, Burr (1984) reported: "In reviewing the literature on movement behavior I was impressed by the amount of disagreement or confusion as to the meaning of moving terms". He was the first author who noticed the necessity to take into account the influence of various parameters of the light stimulus on every type of moving behaviour of microorganism. It is pity that this author did not carry his classification through. Having paid attention to impossibility of a strict delimitation of adapting and non-adapting reactions (as soon as adaptation period may be prolonged), he suggested to use the terms irrespective of adapting characteristics of moving behaviour of biological objects.

\section{NOMENCLATURE PROPOSALS}

Recognizing the propositions of Burr (1984) as necessary we can use the term "lightdependent moving reactions of freely motile organisms" (photoreactions, photoresponses) in the meaning of some sudden moving response of these organism to some kind of alteration of light stimulus (appearance or disappearance of light, changes in its spectral composition, intensity or direction, etc.). Light-dependent behaviour of freely motile organisms, in our sense, is a wider meaning. It includes various light-induced displacements of freely motile microorganisms in space independently of the change in the light stimulus in time (this meaning is equivalent to the term "phototaxis" in its original sense).

Thus, according to our interpretation the light-dependent moving behaviour of freely motile organism (phototaxis) and photoreactions are compatible but not identical meanings: the former is subordinating, while the latter is subordinate (Massjuk \& Posudin, 1991; Massjuk et al., 1991).

The motility performance of the life organisms is the particular case of a broad physical phenomenon: movement. Thus, like some kind of movement the motility of organisms may be described by well-known physical parameters: velocity $(V)$, direction $(r)$ and trajectory $(l)$. These parameters may $\overrightarrow{b e}$ divided into others, less general, for detail characteristics of various types of movement of organisms. For example, velocity may be linear and angular. Both linear and angular velocities may be constant or may vary as a function of time. Certain classes of linear or angular velocity may be divided according to concrete limits of velocity inherent in particular organisms.

According to the previous assessments, the light stimulus in its turn is characterized by parameters such as intensity $(I)$, direction $(s)$, the spectral composition $(\lambda)$, polarization $(\vec{P})$, duration and frequency of light pulses, etc. Similar to the movement parameters, the light parameters may be divided into: the intensity of light that is characterized by absolute magnitude $(I)$ and its gradient in space $(d I / d x)$ and time $(d I / d t)$. According to the parametrical character of either movement of organisms or light stimulus we propose the classification of phototaxes (as the dependence of the organism movement on the light stimulus) on the basis of the parametrical principle for both freely single cells, which is presented schematically in tables 1 and 2. Table 1 demonstrates the phototaxis of individual freely moving organisms (so-called individual or microeffect) while the phototaxis from populations of organisms (group or macroeffect) is shown in table 2. The well-known dependences are shown every case, e.g. $V(I)$ is the dependence 
Intensity $I$ Temporal gradient Spatial gradient Direction $\vec{s}$ Wavelength $\lambda$ Polarization $P$ of intensity $d I / d t$ of intensity $d I / d x$

\begin{tabular}{lcccccc}
\hline Linear velocity $V$ & $V(I)$ & $V(d I / d t)$ & $V(d I / d x)$ & $V(\vec{s})$ & $V(\lambda)$ & $V(P)$ \\
Angular velocity $n$ & $n(I)$ & $n(d I / d t)$ & $n(d I / d x)$ & $n(\vec{s})$ & $n(\lambda)$ & $n(P)$ \\
Direction of movement $\vec{r}$ & $\vec{r}(I)$ & $\vec{r}(d I / d t)$ & $\vec{r}(d I / d x)$ & $\vec{r}(\vec{s})$ & $\vec{r}(\lambda)$ & $\vec{r}(P)$ \\
Trajectory of movement $l$ & $l(I)$ & $l(d I / d t)$ & $l(d I / d x)$ & $l(\vec{s})$ & $l(\lambda)$ & $l(P)$ \\
\hline
\end{tabular}

Table 1. Photoresponses of individual organisms to the different parameters of light stimulus.

of linear velocity of a single cell on the absolute magnitude of intensity of the light stimulus (photokinesis, according to Nultsch \& Häder, 1979, or ortokinesis, according to Fraenkel \& Gunn, 1961); $n(I)$ is the dependence of angular velocity of movement (or frequency of random rotations) on the absolute intensity of light stimulus (or klinokinesis, according to Fraenkel $\&$ Gunn, 1961); $r(s)$ is the dependence of movement direction of organisms on the direction of the light stimulus (phototaxis, according to Diehn et al., 1977); $l(d I / d t)$ is the dependence of movement on the temporal change of the light stimulus intensity (photophobic response, according to Diehn $e t$ al.,1977).

We suggest that the term "photokinesis" means the dependence of the velocity of movement of individual organisms and their groups on various parameters of the light stimulus $(I, d I / d t, d I / d x, l, P, \mathrm{etc}$.$) and the$ term "phototopotaxis" means the dependence of the direction of propagation of those organisms and its groups on the same parameters of the light stimulus. The dependences that are included in the Tables 1 and 2 may be direct or indirect, positive or negative, but these forms of the dependence are not always revealed. Within these terms it is possible to suggest a more detail classification. Particularly, it is possible to distinguish photoortokinesis (dependence of linear velocity of movement on the parameters of light stimulus) and photoklinokinesis (dependence of quantity of rotations at unit of time on parameters of light stimulus). Some dependences have not yet been determined with special terms, e.g., the trajectory of movement, the concentration of organisms, the shape of "ensemble", the relative number of organisms, which perform the photoreactions, on the light stimulus parameters (tabs. 1 and 2). The number of the light stimulus parameters may be augmented with due regard for additional parameters (such as rhythm of the light stimulus, its constant or variable character) or due to possible interactions of various parameters (e.g. wavelength and intensity, change of velocity and direction of propagation, etc.). Thus, the parametrical principle of classification of the light-induced behaviour of the organisms suggested by us, permit not only putting in order the available terminology and the data of interaction of the light stimulus with the specific features of movement of living organism, but to forecast al so new peculiarities and concrete program of further research which can be used for completion of this classification on the strict logical basic. This principle may be proposed for different types of taxa induced by other physical factors.

As to photoreactions it ought to say that they may be expressed through: 1. a change in the velocity (kinctic reaction); 2. a change in 
Intensity $I$ Temporal gradient Spatial gradient Direction $\vec{s}$ Wavelength $\lambda$ Polarization $P$ of intensity $d I / d t$ of intensity $d I / d x$

Concentration of individuals

(optical density) in a

population or colony $N$

$N(I)$

$N(d l / d t)$

$N(d I / d x)$

$N(\vec{s})$

$N(\lambda)$

$N(P)$

Shape (spatial distribution)

of individuals in a

population or colony $S$

$S(I)$

$S(d I / d t)$

$S(d I / d x)$

$S(\vec{s})$

$S(\lambda)$

$S(P)$

Trajectory of movement of

individuals in a

population or colony $L$

$L(I)$

$L(d I / d t)$

$L(d l / d x)$

$L(\vec{s})$

$L(\lambda)$

$L(P)$

Relative number of

individuals performing

a given response $N / N$

$N / N_{o}(I) \quad N / N_{o}(d l / d t)$

$N / N_{o}(d l / d x)$

$N / N_{o}(\vec{s})$

$N / N_{\circ}(\lambda)$

$N / N_{o}(P)$

Table 2. Photoresponses of populations and colonies to the different parameters of light stimulus.

the direction and trajectory of movement (vectorial reaction); and 3 . a simultaneous change in the velocity and direction of movement (photophobic reaction). Thus, we propose to distinguish such meanings as photomovement and control of movement, and within the limits of photomovement phototaxis (in original wider sense) and phototropism. The parametrical principle is proposed for the classification of the lightinduced behaviour of single cells as well as for populations of organisms. The wider meaning "phototaxis" involves the term subordinate to it - "photoreaction", which consists of three phenomelogical types: kinetic, vectorial and phobic ones.

ACKNOWLEDGEMENTS. The authors are grateful to Prof. Dr. Hiroshi Kawai Kobe University Research Center for Inland Sea, Kobe, Japan) for the critical reading of the manuscript.

\section{REFERENCES}

BECKMANN, M. \& P. HEGEMANN -1991-In vitro identification of rhodopsin in the green alga Chlamydomonas. Biochemistry 30: 3692 3697.

BURR, A.H. - 1984- Photomovement behaviour in simple invertebrates. In: Photorecept and Vision Invertevr. Proc. NATO Adv. Study. Inst., Lennoville, N.Y., London, pp. 179-215.

COLOMBETTI, G. \& F. LENCI - 1982- Photoreception and sensory responses in microorganisms, Medicine, Biologie, Environmet 10: 319-325.

COLOMBETTI, G., F. LENCI \& B. DIEHN -1982Responses to photic, chemical and mechanical stimuli. In: D.E. Buetow (ed.), The Biology of Euglena, Academic Press, M.Y. 3: 169 - 195.

DIEHN, B., M. FEINLEIB, W. HAUPT, E. HILDEBRAND, F. LENCI \& W. NULTSCH 1977- Terminology of Behavioural Responses of Motile Microorganisms, Photochem. Photobiol. 26: $559-560$.

DIEHN, B. -1970- Mechanism and computer simulation of the phototactic accumulation of Euglena in a beam of light. Photochem. 
Pholobiol. 11: 407-413.

DIEHN, B. -1979- Photic responses and sensory transduction in Protists. In: H. Autrum (ed.), Handbook of sensory physiology. Comparative and evolution of vision in invertebrates, Springer-Verlag, Berlin, Heidelberg, N.Y., Vol. VII/6A: 23-66.

ENGELMANN, T.W. -1882- Uber die Licht und Fasbenperzeption niederster Organismen. Pflugers Arch, 29: 387-400.

FEINLEIB, M. - 1977-Photomovement in microorganism's strategies of response. In: A. Castellani (ed.), Research in Photobiology, Plenum Publ. Co., pp.71-84.

FEINLEIB, M. -1978-Photomovement of microorganisms. Photochem. Photobiol. 27: 849-854.

FEINLEIB, M. -1980- Photomotile responses in Flagellates. In: F. Lenci, G. Colombetti (eds), Photoreception and sensory transduction in a neural organisms, Plenum Press, N.Y., pp. 4568.

FLORES-MOYA, A., Y. I. POSUDIN, J. A. FERNÁNDEZ, F. L. FIGUEROA \& H. KAWAI -2002.- Photomovement of the swarmers of the brown algae Scytosiphon lomentaria and Petalonia fascia: effect of photon irradiance, spectral composition and UV dose. J. Photochem. Photobiol. B: Biol. 66: 134-140.

FRAENKEL, G. S. \& D. L. GUNN -1961- The Orientation of Animals. Kineses, taxes and compass reactions. Dover Publications, Inc. N.Y., $376 \mathrm{pp}$.

GOVORUNOVA, E. G., I. A. ALTSCHULER, D.P. HÄDER \& O. A. INESHCHEKOV-2000- A novel express bioassay for detecting toxic substances in water by recording rhodopsinmediated photoelectric responses in Chlamydomonas cell suspensions Photochem. Photobiol. 72: 320-326.

GOVORUNOVA, E. G., O. A. SINESHCHEKOV \& P. HEGEMANN -1997- Desensitization and dark recovery of the photoreceptor current in Chlamydomonas reinhardtii. Plant Physiol. 115: 633-642.

GOVORUNOVA, E. G., O. A. SINESHCHEKOV, W. GÄRTNER, A. S. CHUNAEV \& P. HEGEMANN, -2001- Photoreceptor current and photoorientation in Chlamydomonas mediated by 9 -deethylchlamyrodopsin. Biophysical J, 81: 2897-2907.
GRAHAM, L. E. \& L. W. WILCOX - 2000.- Algae. Prentice Hall, Upper Saddle River, NJ, USA, $640 \mathrm{pp}$.

HÄDER, D.-P. -1979- Control of locomotion. In: W. Haupt \& M.Feinleib (eds.) Physiology of Movements, Springer-Verlag, Berlin, Heidelberg, N.Y., pp. 268-309.

HÄDER, D. P. - 1996- Mechanisms of photoreception: energy and signal transducers. Light and Energy Source and Information Carrier in Plant Physiology. Plenum Press, New York, pp. 185194.

HÄDER, D. P. \& M. LEBERT -1998- The photorecerptor for phototaxis in the photosynthetic flagellate Euglena gracilis. Photochem. Photobiol. 60: 260-265.

HALLDAL, P. -1958- Action spectrum of phototaxis and related problems in Volvocales, Ulvagametes and Dinophyceae, Phys. Plant. 11: 118-153.

HAUPT, W. -1983-Photoreception and photomovement. Phill. Trans. Soc. London, B 303: 467-478.

HEGEMANN, P., W. GÄRTNER \& R. UHL - 1991All-trans retinal constitutes the functional chromophore in Chlamydomonas rhodopsin. Biophys J. 60: 1477-1489.

HOEK, van den C., D. G. MANN \& H. M. JAHNS -1995-Algae: An Introduction to Phycology, Cambridge University Press, UK, 623 pp.

HOLLAND, E. M., H. HARZ, R. UHL \& P. HEGEMANN -1997-Control of phobic behavioral responses by rhodopsin-induced photocurrents in Chlamydomonas. Biophysical J. 73: 1395-1401.

HORIGUSHI, T., H. KAWAI, M. KUBOTA, T. TAKAHASHI \& M. WATANABE - 1999. Phototactic responses of four marine dinoflagellates with different types of eyespot and chloroplast. Phycological Research 47: 101 107.

JAHN, T. L. \& B. C. BOVEE -1968- Locomotive and motile response in Euglena. In: D. E. Buetow (ed.), The Biology of Euglena. Acad. Press, N.Y., London, vol. I, pp. 45-107.

KAWAI, H. \& G. KREIMER -2001- Sensory mechanisms: Phototaxis and light perception in algae. In: J. Green \& B. S. C. Leadbeater (eds.), The Flagellates. Taylor and Francis, London, pp. 124-146.

KONEV, S. V. \& I. D. VOLOTOVSKY -1979- 
Photobiology, Belorussian State University, Minsk.

KREIMER, G. - 1994- Cell biology of phototaxis in flagellated algae. Int. Rev. Cytol. 148: 229-310.

KRITSKY, M. S. -1982- Photoregulation of metabolism and ontogenesis of heterotropic microorganisms, Uspekhi microbiologii 17: 41 61.

KUZNICKI, O. L. \& E. MIKOLAJCZYK -1982Motility and behaviour: contributed paper session in memory of Professor Theodore L. Jahn. In: Progress in Photozoology. Proc. VI Intern. Congr. Protosoology Spec. Congr. Vol. of Acta Protozoologica, part I.: 149-157.

LEBERT, M. \& D. P. HÄDER -2000- Photoreception and phototaxis in flagellated algae. Res. Adv. in Photochem. \& Photobiol. 1: 201-226.

LEE, R. E.- 1989-Phycology ( $2^{\text {nd }}$ ed.), Cambridge University Press, NY, USA, 645 pp.

LENCI,F.\& G. COLOMBETTI-1978- Photobehaviour of microorganisms: a biophysical approach, Ann. Rev. Bioeng. 7: 341-361.

LENCI, F., D. P. HÄDER \& G. COLOMBETTI 1984- Photosensory responses of freely motile microorganisms. In: F. Lenci \& G. Colombetti (eds.), Membrane and sensory transduction. Plenum Press, N.Y., London, pp. 199 -229.

LENCI, F. - 1982- Photomovement of microorganisms. In: C. Helene (ed.), Trends in Photobiology, Plenum Press, N.Y., London, pp. 421-435.

MARTYNENKO, A. I., Y. I POSUDIN, N. P. MASSJUK \& G.G. LILITSKAYA - 1996- Effect of external factors on photomovement of microorganisms. Algologia 6: 150-155.

MASSJUK, N. P. \& Y. I. POSUDIN-1991-Logical Fundamentals of Classification of Behaviour of Motile Microorganisms. Kiev, Agr. Academy Publ., 36 pp.

MASSJUK, N. P., Y. I. POSUDIN, M. I. RADCHENKO \& A. N. SHEIKO -1991- The parametrical principle of the classification of photomovement of organisms. J. Photochem. Photobiol.10: 269-271.

MASSJUK, N. P. -1993-Evolutional aspects of morphology of eukariotic algae. Kiev, Naukova dumka, $256 \mathrm{pp}$.

MATSUDA, A., K. YOSHIMURA, O. A. SINESHCHEKOV, M. HIRONO \& R. KAMIYA -1998- Isolation and characterization of novel Chlamydomonas mutants that display phototaxis but not photophobic response// Cell Motility and the Cytoskeleton .-1998.-41: 353-362.

MIKOLAJCZYK, E. \& B. DIEHN -1978Morphological in Euglena gracilis induced by treatment with CTAB (Cetyltrimethylammonium bromide) and Triton X-100: Correlations with effects on photophobic behavioural responses, $J$. Photozool. 25: 461-470.

MIKOLAJCZYK,E.\& B.DIEHN-1979-Mechanosensory responses and mechanoreception in Euglena gracilis. Acta protozoologica 18: 591-602.

MOREL-LAURENS, H. M. L. \& M. FEINLEIB 1983- Photomovement in an "eyeless" mutant of Chlamydomonas. Photochem. Photobiol. 37: 189-194.

NULTSCH, W. - 1975-Phototaxis and photokinesis. In: M.J. Carlile (ed.), Primitive Sensory and Communication Systems: The Taxes and Tropisms of Microorganisms and Cells, Acad. Press, N.Y., San Francisco, pp. 29-90.

NULTSCH, W. -1980- Photomotile responses in gliding organisms and bacteria. In: F. Lenci and G. Colombetti (eds.), Photoreception and sensory transduction in a neural organisms, Plenum Press, N.Y., pp. 69-88.

NULTSCH, W. \& D. P. HÄDER -1979- Photomovement of motile microorganisms. Photochem. Photobiol. 29: 423- 437.

NULTSCH, W. - 1983-The photocontrol of movement of Chlamydomonas. In: D.J. Cosens and D. Vince-Price (eds.), The Biology of photoreception. Soc. Experiment. Biology, Symposium XXXVI, pp. 521-539.

PFAU, J., W. NULTSCH \& U. A. RUFFER - 1983A fully automated and computerized system for simultaneous measurement of motility and phototaxis in Chlamydomonas. Arch. Microbiol. 135: 259-264.

PHOTOMOVEMENT (D.P. Häder, M. Lebert, eds.). -2001.- Elsevier Science, Amsterdam-LondonNew York-Oxford-Paris-Shannon-Tokyo, 925 pp.

POSUDIN, Y. I. -1982- Photobehaviour of Euglena gracilis. Uspekhi sovremennoi biologii 93: 230235.

POSUDIN, Y. I. -1985- Laser microfluorimetry of biological objects. Vysshcha shkola, Kiev, 108 pp.

POSUDIN, Y. I., V. R. KONONCHUK, N. P. MASSJUK \& G. G. LILITSKAYA -1991 a- 
Mechanisms of photoreception of Dunaliella salina. Algologia 1: 24-34.

POSUDIN, Y.I., N. P. MASSJUK, G. G. LILITSKAYA - 1993-Effect of calcium ions on photomovement of two species of Dunaliella Teod. Algologia $3: 16-23$.

POSUDIN, Y. I., N. P. MASSJUK \& G. G. LILITSKATA - 1996- Photomovement parameters as test-functions during biomonitoring. Polish $J$. Env. Sciences 5: 51-57.

POSUDIN, Y. I., N. P. MASSJUK, G. G. LILITSKAYA \& M. I. RADCHENKO - 1990- Phototopotaxis of two species of Dunaliella in ultraviolet part of spectrum. Biophysics 35: 968-971.

POSUDIN, Y. I., N. P. MASSJUK, G. G. LILITSKAYA \& M. G. GOLUBKOVA -1992a- Effect of ionising radiation on photomovement of algae. Radiobiology 2: 292-298.

POSUDIN, Y. I., N. P. MASSJUK, G. G. LILITSKAYA \& M. I. RADCHENKO-1991b.- Phototopotaxis of two species of Dunaliella. Ukrainian Botanical J. 48: 48-53.

POSUDIN, Y. I., N. P. MASSJUK, G. G. LILITSKAYA \& A. Y. SHEVCHENKO - 1995.- Effect of sodium azide on photomovement of two species of Dunaliella Teod. Physiology of Plants 42: 432-434.

POSUDIN, Y. I., N. P. MASSJUK, G. G. LILITSKAYA \& M. I. RADCHENKO - 1992b- Photomovement of two species of Dunaliella Teod. Algologia 2: 37-47.

POSUDIN, Y. I., N. P. MASSJUK, M. I. RADCHENKO \& G. G. LILITSKAYA - 1988- Photokinetic reactions of Dunaliella. Microbiologia 57: 10011006.

POSUDIN, Y. I. \& N. P. MASSJUK -1996Diffractional mechanism of photoreception of unicellular green flagellated algae. Algologia 6: 369-376.

SEDOVA, T. V.- 1977- Fundamentals of algal cytology, Nauka, Leningrad, $172 \mathrm{pp}$.

SINESHCHEKOV, O. A. \& E. G. GOVORUNOVA -1999.- Rhodopsin-mediated photosensing in green flagellated algae. Trends in plant science 4: 58-63.

SINESCHEKOV, O. A. \& F. F. LITVIN -1982Photoregulation of movement of microorganisms. Uspekhi microbiologii 17: $62-87$.
TOPACHEVSKY, A. V.\& N. P. MASSJUK - 1984Freshwater algae of the Ukrainian SSR. Vyshcha shkola, Kiev, 334 pp.

WITMAN, G. B. - 1993-Chlamydomonas phototaxis. Trends Cell Biol. 3: 403-408.

YOSHIHARA, S., F. SUZUKI, H. FUJITA, X. X. GEN \& M. IKEUCHI -2000- Novel putative photoreceptor and regulatory genes required for the positive phototactic movement of the unicellular motile cyanobacterium Synechococystis sp. PCC 6803. Plant Cell Physiol. 41: 12991304.

Aceptado para su publicación en septiembre de 2002

Address of the authors. N. P. MASSJUK: Institute of Botany of National Academy of Sciences of Ukraine, Tereshenkivska St.,2, Kyiv, 01601,Ukraine. Y. I. POSUDIN: National Agricultural University, Geroiv Oborony st.,15, Kyiv, 03041, Ukraine. 